\title{
KARAKTERISTIK PEREMPUAN DAN KONTRIBUSI PADA PENDAPATAN RUMAH TANGGA NELAYAN TRADISIONAL DI KELURAHAN BATULUBANG KECAMATAN LEMBEH SELATAN KOTA BITUNG PROVINSI SULAWESI UTARA
}

\author{
Gloria M.S. Doelelia1; Jardie A. Andaki2; Djuwita R.R. Aling² \\ 1)Mahasiswa Fakultas Perikanan dan Ilmu Kelautan Universitas Sam Ratulangi Manado \\ 2)Staff Pengajar Fakultas Perikanan dan IImu Kelautan Universitas Sam Ratulangi Manado \\ Koresponden email: gloriamsdoelelia@gmail.com
}

\begin{abstract}
This study aims to determine the characteristics of female workers and contribute to the income of traditional fishing households in Batulubang Village, South Lembeh District, Bitung City, North Sulawesi Province.

Data collection was carried out on female workers and their contribution to the income of traditional fishing families in Batulubang Village, South Lembeh Sub-District, Bitung City, North Sulawesi Province, by observation, interviews, and questionnaires. The data obtained was processed and analyzed descriptively. Descriptive analysis is intended to provide discussion or interpretation of data to obtain conclusions. Descriptive data analysis will provide a description of the information with sentences associated with existing theories, through simple calcutations such as; addition, average and percentage.

The research and discussion can be concluded, as follows: 1) catechteristics of women workers in this case the wives of fishermen, choosing to work because to help support the family economy.Most female workers or wives of fishermen work in the range of ages 41-50 because at this age the respondents of fishermen's wives are wiser in taking the initiative to do a job. However, education is not the main factor for work because in the work carried out by the respondent, only attitudes and skills are needed in the work of responding to the wife of the fisherman; 2) contributions can be seen from various types of work carried out by fishermen's wives, which amounted to $36.89 \%$ of the total income of the fishermen's family.
\end{abstract}

Key Words: traditional fishermen; women's controversy; income

\begin{abstract}
Abstrak
Penelitian ini bertujuan mengetahui karakteristik pekerja perempuan dan kontribusi pada pendapatan rumah tangga nelayan tradisional di Kelurahan Batulubang Kecamatan Lembeh Selatan Kota Bitung Provinsi Sulawesi Utara.

Pengumpulan data dilakukan pada pekerja perempuan dan kontribusinya pendapatan keluarga nelayan tradisional di Kelurahan Batulubang Kecamatan Lembeh Selatan Kota Bitung Provinsi Sulawesi Utara, dengan cara observasi, wawancara, dan kuisioner. Data yang diperoleh diolah dan dianalisis secara deskriptif. Analisis deskriptif dimaksud untuk memberikan bahasan atau penafsiran terhadap data-data untuk memperoleh kesimpulan. Analisis data deskriptif akan memberikan gambaran keterangan dengan kalimat-kalimat yang dihubungkan dengan teori yang ada, melalui perhitungan sederhana seperti; penjumlahan, rata-rata dan persentase.

Penelitian dan pembahsan dapat disimpulkan, sebagai berikut : 1) katekteristik pekerja perempuan dalam hal ini istri nelayan, memilih bekerja karena untuk membantu menopang perekonomian keluarga. Pekerja perempuan atau istri nelayan kebanyakan bekerja pada kisaran umur 41-50 karena pada umur dewasa ini responden istri nelayan lebih bijak dalam mengambiitinisiatif untuk melakukan suatu pekerjaan. Namun pendidikan tidak menjadi faktor utama untuk bekerja karena dalam pekerjaan yang dilakukan oleh responden hanya diperlukan sikap dan keterampilan dalam melakukan pekerjaan responden istri nelayan; 2) kontribusi dapat dilihat dari berbagai jenis pekerjann yang dilakukan istri nelayan yaitu sebesar $36,89 \%$ dari total pendapatan keluarga nelayan.
\end{abstract}

Kata kunci: nelayan tradisonal; kontrobusi perempuan; pendapatan

\section{PENDAHULUAN}

Partisipasi perempuan dalam pembangunan di segala bidang mutlak diperlukan, karena merupakan modal dasar dalam pembangunan. Guna mensejajarkan tenaga kerja perempuan dalam konsep-konsep kerja bukan semata-mata masalah mengejar kepentingan segi ekonomis atau peningkatan pendapatan, akan tetapi juga bertujuan untuk meningkatkan partisipasi atau peranan perempuan dalam masyarakat (Aninomous, 2000).

Sebagian besar dari perempuan yang tinggal di Indonesia berupaya menutupi kekurangan kebutuhan keluarga karena penghasilan suami kecil 
dan tidak menentu.Mereka juga terpaksa bekerja karena suami mendapat musibah, sakit serta kecelakaan sehingga perempuan menjadi kepala rumah tangga tidak punya pilihan. Perempuan itu haruslah bijak dalam mengatur belanja keluarga rumah tangga. Pengeluaran rutin sehari-hari merupakan kebutuhan pokok seperti makanan dan transport sekolah, haruslah diatur sedemikian rupa supaya tidak melebihi penghasilan ibu yang didapat sehari- hari (Ari dkk., 2000).

Salah satu kelurahan yang memiliki nelayan yang ada di Kota Bitung ialah Kelurahan Batulubang. Kelurahan Batulubang terletak di Pulau Lembeh bagian Selatan yang memiliki komunitas nelayan tradisional. Penghasilan nelayan tradisional sangat tergantung pada musim. Pada musim baik atau cuaca tidak berangin dan berombak, maka nelayan dapat melakukan usaha penangkapan ikan, sedangkan pada musim buruk atau cuara yang berangin dan berombak nelayan sebaliknya tidak dapat melakukan usaha penangkapan ikan. Faktor-faktor pembatas inilah yang menyebabkan nelayan perlu mencari alternatif pekerjaan lain difuar usaha penangkapan ikan. Peran anggota keluarga menjadi penting guna mempertahankan kehidupan keluarga nelayan. Anggota keluarga yang berperan penting dalam pekerjaan diluar pekerjaan usaha penangkapan ikan yaitu ibu rumah tangga.

Hasil pengamatan di kelurahan Batulubang terdapat berbagai usaha yang dilakukan oleh ibu rumah tangga dengan karakteristik yang berbeda-beda menurut jenis pekerjaan. Pekerjaanpekerjaan ini memberikan kontribusi pada pendapatan keluarga nelayan, kontribusi ini dapat mempengaruhi tingkat pendapatan yang berimplikasi pada pemenuhan kebutuhan hidup dari keluarga nelayan.

Berdasarkan latar belakang seperti yang dikemukakan sebelumnya, maka perlu adanya penelitian tentang karakteristik pekerja perempuan dan kontribusi pada pendapatan rumah tangga nelayantradisional di Kelurahan Batulubang Kecamatan Lembeh Selatan Kota Bitung Provinsi Sulawesi Utara.

Berdasarkan latar belakang penelitian, maka yang menjadi masalah dalam penelitian ini, yaitu 1) bagaimana karakteristik pekerja isteri nelayan tradisional di Kelurahan Batulubang Kecamatan Lembeh Selatan Kota Bitung Provinsi Sulawesi Utara, dan 2) bagaimana kontribusi pendapatan istri nelayan tradisional di Kelurahan Batulubang Kecamatan Lembeh Selatan Kota Bitung Provinsi Sulawesi Utara.

\section{METODE PENELITIAN}

Metode yang digunakan dalam penelitian ini adalah metode survei. Metode survei merupakan penelitian yang mengambil sampel dari satu populasi dan menggunakan kuesioner sebagai alat pengumpul data yang pokok. Singarimbun dan Effendi (1995), menyatakan hasil akhir pengumpulan data berupa gambaran lengkap permasalahan yang disajikan dalam bentuk tabel-tabel data dan variabelvariabel yang dianalisis secara kuantitatif.

Pengumpulan data dilakukan pada pekerja perempuan dan kontribusi pada pendapatan rumah tangga nelayan tradisional. Pengumpulan data dilakukan dengan cara observasi, wawancara dan pengisian kuesioner.

Data yang diperoleh diolah dan dianalisis secara deskriptif. Analisis deskriptif merupakan metode yang 
digunakan untuk menganalisis data dengan cara mendeskripsikan atau menggambarkan data yang telah terkumpul sebagaimana adanya tanpa bermaksud membuat kesimpulan yang berlaku untuk umum atau generalisasi (Best, 1982 dalam Sukardi, 2004). Analisis deskriptif dimaksud untuk memberikan bahasan atau penafsiaran terhadap data-data untuk memperoleh kesimpulan.

Analisis data deskriptif akan memberikan gambaran keterangan dengan kalimat-kalimat yang dihubungkan dengan teori yang ada,

\begin{tabular}{|c|l|c|c|}
\hline No. & \multicolumn{1}{|c|}{ Jenis Pekerjaan } & Jumlah & Presentase \\
\hline 1. & Ketua RT & 2 & 8 \\
\hline 2. & Petibo & 8 & 32 \\
\hline 3. & Kuliner & 7 & 28 \\
\hline 4. & Jual Bensin & & 4 \\
\hline 5. & Warung Sembako & 6 & 24 \\
\hline 6. & Warung Pulsa & 1 & 4 \\
\hline & & 25 & 100 \\
\hline
\end{tabular}

Sumber : Data Primer (2019)

Berdasarkan jenis pekerjaan responden istri nelayan di atas dapat menunjukan bahwa 25 responden istri nelayan dengan keterampilan paling banyak yaitu responden istri nelayan yang memiliki pekerjaan sebagai Petibo 8 (32\%), selanjutnya bekerja dengan jenis pekerjaan dibidang Kuliner yaitu 7 (28\%). Warung Sembako 6 (24\%), kemudian bekerja sebagai Ketua RT 2 $(8 \%)$, dan sisanya yaitu 1 responden istri nelayan memiliki Warung Pulsa dan 1 responden istri nelayan Penjual Bensin..

Hasil penelitian ini menunjukan bahwa responden dengan jenis pekerjaan sebagai Petibo merupakan pilihan paling banyak dari jenis pekerjaan responden istri nelayan lainnya, karena responden istri nelayan merasa lebih gampang dalam melalui perhitungan sederhana seperti; penjumlahan, rata-rata dan persentase.

\section{HASIL DAN PEMBAHASAN Jenis Pekerjaan Isteri Nelayan}

Jenis pekerjaan yang dimaksud dalam penelitian ini ialah pekerjaan yang dilakukan oleh responden istri nelayan dengan keterampilan masing-masing dari setiap responden istri nelayan. Keragaman keterampilan yang dimiliki responden istri nelayan berdasarkan jenis pekerjaan dapat dilihat pada tabel berikut : 
sangat sesuai dengan pekerjaan ibu rumah tangga, hal kegiatan sehari-hari tidak lepas memasak baik untuk keluarga. Hasil ini sesuai dengan pernyataan Sajogyo (1987), bahwa perempuan memiliki tiga peranan, yaitu (1) penyumbang tenaga dalam pekerjaan rumah tangga seperti memelihara anak, memelihara rumah, pengaturan konsumsi rumah tangga dan pemeliharaan kesehatan serta mencari nafkah di luar rumah tangga; (2) pengatur/pengambil keputusan; (3) di luar rumah tangga sebagai pendukung beberapa lembaga/organisasi social, ekonomi, budaya dan politik, ketiga peranan ini disebut dengan peran ganda perempuan.

Karakteristik isteri nelayan di Batulubang dapat dikatakan sebagai perempuan berperan ganda, yaitu bekerja di rumah sebagai ibu rumah tangga dan di luar rumah membantu meningkatkan pendapatan keluarga. Dalam hal ini terdapat dua pola peranan perempuan, yaitu perempuan atau isteri nelayan yang yang mengerjakan pekerjaan rumah tangga, dan perempuan atau isteri nelayan yang melakukan pekerjaan rumah tangga dan pekerjaan mencari nafkan. Karakteristik ini sama dengan yang diungkapkan White dan Hastuti (1980), bahwa terdapat dua pola peranan perempuan: (1) perempuan hanya berperan dalam pekerjaan rumah tanga, (2) perempuan yang mempunyai dua peranan, yaitu peranan dalam pekerjaan mencari nafkah dan pekerjaan rumah tangga.

\section{Pendapatan Keluarga Nelayan}

Pendapatan bisa diartikan sebagai penerimaan yang dihasilkan atas suatu usaha atau kegiatan. Menurut Putong (2002) pendapatan adalah semua jenis pendapatan, termasuk pendapatan yang diperoleh tanpa memberikan sesuatu kegiatan apapun yang diterima oleh penduduk suatu negara.

Pendapatan secara umum adalah uang yang diterima seseorang atau perusahaan dalam bentuk gaji (wages), upah (salaries), sewa (rent), bunga (interes), laba (profit), dan sebagainya. Kondisi seseorang dapat diukur dengan menggunakan konsep pendapatan yang menunjukan jumlah seluruh uang yang diterima oleh seorang selama jangka waktu tertentu (Pass, 1997).

Berdasarkan hasil penelitian, pendapatan responden istri nelayan di Kelurahan Batulubang bervariasi. Pendapatan responden istri nelayan dihitung berdasarkan penghasilan yaitu sebagai penjual kuliner,petibo, warung sembako, ketua RT, jual bensin dan warung pulsa. Pendapatan dihitung dari hasil yang diperoleh responden selama satu bulan. Demikian merupakan tabel pendapatan keluarga responden istri nelayan. 
Tabel 2. Sebaran Pendapatan Keluarga Nelayan dan Kontribusi Pendapatan Isteri Nelayan per Tahun di Kelurahan Batulubang

\begin{tabular}{|c|c|c|c|c|}
\hline \multirow{2}{*}{ No. } & \multicolumn{2}{|c|}{ Pendapatan Keluarga Nelayan } & \multirow[b]{2}{*}{ Jumlah } & \multirow{2}{*}{$\begin{array}{l}\text { Kontribusi Istri } \\
\text { Nelayan }\end{array}$} \\
\hline & Suami & Istri & & \\
\hline 1. & 36.000 .000 & 12.000 .000 & 48.000 .000 & 25,00 \\
\hline 2. & 38.400 .000 & 42.000 .000 & 80.400 .000 & 52,24 \\
\hline 3. & 27.600 .000 & 9.600 .000 & 37.200 .000 & 25,81 \\
\hline 4. & 30.000 .000 & 48.000 .000 & 78.000 .000 & 61,54 \\
\hline 5. & 18.000 .000 & 28.800 .000 & 46.800 .000 & 61,54 \\
\hline 6. & 18.000 .000 & 12.000 .000 & 30.000 .000 & 40,00 \\
\hline 7. & 60.000 .000 & 8.400 .000 & 68.400 .000 & 12,28 \\
\hline 8. & 19.200 .000 & 18.000 .000 & 37.200 .000 & 48,39 \\
\hline 9. & 18.000 .000 & 4.200 .000 & 22.200 .000 & 18,92 \\
\hline 10. & 60.000 .000 & 45.000 .000 & 105.000 .000 & 42,86 \\
\hline 11. & 60.000 .000 & 38.400 .000 & 98.400 .000 & 39,02 \\
\hline 12. & 18.000 .000 & 9.600 .000 & 27.600 .000 & 34,78 \\
\hline 13. & 12.000 .000 & 36.000 .000 & 48.000 .000 & 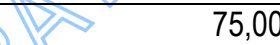 \\
\hline 14. & 19.200 .000 & 8.400 .000 & 27.600 .000 & 30,43 \\
\hline 15. & 16.800 .000 & 27.600 .000 & 44.400 .000 & 62,16 \\
\hline 16. & 12.000 .000 & 14.400 .000 & 26.400 .000 & 54,55 \\
\hline 17. & 30.000 .000 & 6.000 .000 & 36.000 .000 & 16,67 \\
\hline 18. & 72.000 .000 & 4.000 .000 & 76.000 .000 & 5,26 \\
\hline 19. & 8.400 .000 & 7.200 .000 & 15.600 .000 & 46,15 \\
\hline 20. & 48.000 .000 & 15.000 .000 & 63.000 .000 & 23,81 \\
\hline 21. & 36.000 .000 & 9.600 .000 & 45.600 .000 & 21,05 \\
\hline 22. & 12.000 .000 & 20.760 .000 & 32.760 .000 & 63,37 \\
\hline 23. & 24.000 .000 & 22.200 .000 & 46.200 .000 & 48,05 \\
\hline 24. & 24.000 .000 & 8.400 .000 & 32.400 .000 & 25,93 \\
\hline 25. & 72.000 .000 & 6.000 .000 & 78.000 .000 & 7,69 \\
\hline Rata-rata & 31.584 .000 & 18.462 .400 & 50.046 .400 & 36,89 \\
\hline
\end{tabular}

Sumber : Pengolahan Data Primer (2019).

Berdasarkan hasil penelitian dan analisis deskriptif didapat hasibrata-rata pendapatan keluarga nelayan tradisional per tahun Rp. 50.046.400. Jika dirataratakan pendapatan nelayan per bulan yaitu Rp. 4.170.533. Pendapatan ini sudah merupakan gabungan antara pendapatan dari usaha menangkap ikan (Rp. 31.584.000) dan pendapatan dari usaha isteri nelayan (Rp. 18.462.400), yang melakukan berbagai pekerjaan di dalam dan di luar pekerjaan terkait perikanan.

\section{Menurut Mubyarto} pendapatan rumah tangga diartikan sebagai pendapatan yang diperoleh seluruh anggota keluarga, baik suami, istri, maupun anak. Sedangkan Badan Pusat Statistik (1998) menyebutkan bahwa pendapatan dan penerimaan rumah tangga adalah seluruh pendapatan dan penerimaan yang diterima oleh seluruh anggota rumah tangga ekonomi yang terdiri dari: 1) pendapatan dari upah/gaji yang mencakup upah/gaji yang diterima seluruh anggota rumah tangga ekonomi yang bekerja sebagai buruh dan merupakan imbalan bagi pekerjaan yang dilakukan untuk suatu perusahaan/ majikan/ instansi tersebut baik uang maupun barang dan jasa; 2) pendapatan dari usaha seluruh anggota rumah tangga yang berupa pendapatan kotor yaitu selisih jual barang dan jasa yang diproduksi dengan biaya produksinya; 3) pendapatan lainnya yaitu pendapatan di luar gaji/upah yang menyangkut usaha lain dari, pertama: perkiraan sewa rumah milik sendiri. kedua: bunga, deviden, royalty, paten, sewa/kontrak, lahan, rumah, gedung, bangunan, dan 
peralatan; dan 4) pendapatan rumah tangga dapat berasal dari lebih dari satu pendapatan, sumber pendapatan yang beragam tersebut dapat terjadi karena anggota rumah tangga yang bekerja melakukan lebih dari satu pekerjaan atau masing-masing anggota rumah tangga mempunyai kegiatan yang berbeda antara yang satu dengan yang lainnya.

Karakteristik pendapatan yang ditunjukkan pada Lampiran 3, khusus untuk isteri nelayan menggambarkan baik suami dan isteri melakukan berbagai pekerjaan yang berbeda-beda sesuai dengan keterampilan yang dimiliki isteri. Demikian pula suami dalam mencari sumber pendapatan tidak sepenuhnya didapat dari pekerjaan sebagai nelayan, karena pada musim tidak baik maka nelayan akan mengganti profesi sebagai tukang ojek, buruh bangunan, buruh toko dan buruh perkebunan.

Berbagai jenis pekerjaan yang dilakukan isteri nelayan menghasilkan pendapatan yang dapat menopang kebutuhan rumah tangga nelayan tradisional. Pendapatan dari isteri nelayan melalui pekerjaan berkontribusi berbeda-beda antar responden sesuai dengan pekerjaan dan jumlah pendapatan yang dihasilkan isteri nelayan tradisional di Kelurahan Batulubang.

\section{Kontribusi Pendapatan Isteri Nelayan}

Berdasarkan hasil perhitungan kontribusi pendapatan responden istri nelayan rata-rata berjumlah $36,89 \%$ (Tabel 6). Pendapatan ini berasal dari berbagai pekerjaan yang dilakukan istri nelayan dapat dilihat pada Lampiran 3. Hal mana sebagian besar pendapatan istri nelayan berasal dari usaha petibo, selanjutnya dari usaha kuliner, warung sembako, sebagai ketua RT, dan yang paling sedikit bekerja sebagai penjual bensin dan warung pulsa.

Berbagai jenis pekerjaan ini, dilakukan untuk menopang ekonomi keluarga. Dalam hal ini istri nelayan mengerjakan berbagai pekerjaan dikarenakan pendapatan dari usaha penangkapan ikan oleh suami tidak mencukupi untuk memenuhi kebutuhan keluarga, di samping itu pekerjaan nelayan tidak tetap karena dipengaruhi oleh keadaan iklim. Pada waktu musim baik biasa nelayan mencurahkan banyak waktu pada pekerjaan menangkap ikan, demikian sebaliknya. Curahan waktu nelayan akan berkontribusi pada pendapatan keluarga sesuai jumlah curahan waktu pekerjaan, akan semakin menurun dengan semakin rendahnya curahan waktu pekerjaan.

Menurut Sajogyo (1987), peran perempuan dan laki-laki dalam pekerjaan dapat diukur dengan curahan waktu dan pendapatan yang dihasilkan dan pekerjaan. Konsep nilai waktu pada dasarnya melalui pengertian "nilai pekerjaan", hal mana sumbangan lakilaki dan perempuan anggota rumah tangga dapat dibandingkan dan dapat diukur, guna mengetahui kedudukan perempuan dalam perekonomian rumah tangga. Sedangkan Kusnadi (2009), memberi nilai terhadap waktu maka pekerjaan rumah tangga yang secara ekonomis tidak menghasilkan imbalan kerja dapat diberi nilai yang wajar secara umum, dalam masyarakat nelayan pesisir perempuan memegang peranan yang amat penting untuk ikut serta menjaga kelangsungan hidup rumah tangganya. Selain harus bertanggung jawab terhadap urusan domestik atau rumah tangga, mereka juga harus membantu tugas atau pekerjaan suami dan tertibat aktif mencari nafkah untuk 
menopang pemenuhan kebutuhan rumah tangga.

Pekerjaan nelayan sangat dipengaruhi oleh iklim karena jika musim tidak baik, pekerjaan nelayan akan terhambat karena keadaan cuaca yang berombak, sehingga proses penangkapan ikan tidak dapat dilakukan karena dapat membahayakan nelayan yang memaksa untuk melaut. Pada kondisi ini dibutuhkan sumber pendapatan lain, selain penangkapan ikan. Istri nelayan dengan berbagai jenis pekerjaan yang dilakukan dapat membantu kondisi paceklik nelayan yang disebabkan oleh faktor cuaca. Kehilangan sumber pendapatan nelayan dapat dikompensasi dari pendapatan berbagai pekerjaan yang dilakukan oleh istri nelayan. Kontribusi pendapatan istri nelayan sebesar $36,89 \%$ merupakan kontribusi yang cukup besar membantu kebutuhan keluarga nelayan.

\section{KESIMPULAN}

Berdasarkan hasil penelitian dan pembahasan dapat disimpulkan :

1. Katekteristik pekerja perempuan dalam hal ini istri nelayan, memilih bekerja karena untuk membantu menopang perekonomian keluarga. Pekerja perempuan atau istri nelayan kebanyakan bekerja pada kisaran umur 41-50 karena pada umur dewasa ini responden istri nelayan lebih bijak dalam mengambil inisiatif untuk melakukan suatu pekerjaan. Namun pendidikan tidak menjadi faktor utama untuk bekerja karena dalam pekerjaan yang dilakukan oleh responden hanya diperlukan sikap dan keterampilan dalam melakukan pekerjaan responden istri nelayan.

2. Kontribusi dapat dilihat dari berbagai jenis pekerjann yang dilakukan istri nelayan yaitu sebesar $36,89 \%$ dari total pendapatan keluarga nelayan.

\section{DAFTAR PUSTAKA}

Anonimous, 2000. Peran Serta Ibu Rumah Tangga Dalam Pengembangan Kebudayaan Tradisional di Daerah Riau. Balai Kajian DanTradisional, Tanjung Pinang.

Ari, S., Chamsiah, D., Dina, L., Johanna, A.P., Lilik, S., Lusi, U., Sita, Sri K, Surwani, A.R., 2000. Perempuan yang Menuntun. Ashoka Indonesia Bandung.

Badan Pusat Statistik. 1998. Indikator Kesejahteraan Rumah Tangga 1998. Jakarta: BPS.

Haryanto, S., 2009. Peran Aktif Wanita dalam Meningkatkan Pendapatan Rumah Tangga Miskin. Model Ekonomi Rumah Tangga Miskin, (Online), (http:/www.google.com./htm), diakses 08 Mei 2009).

Irwan, A., 2001. Sangkan Paran Gender. Yogyakarta. Pustaka Pelajar Affif.

Kusnadi, 2009. Keberdayaan Nelayan dan Dinamika Ekonomi Pesisir. Diterbitkan atas Kerjasama Pusat Penelitian Wilayah Pesisir dan Pulau-Pulau Kecil Lembaga Penelitian, Universitas Jember dengan Penerbit Ar-Ruzz Media. Yogyakarta.

Marsita, 2015. "Sejarah Kelurahan Batulubang di Pulau Lembeh" Skripsi. Jurusan IImu Sejarah, Manado : Fakultas IImu Budaya.

Mubyarto, 1998. Pembangunan dan Pemberdayaan Masyarakat. Yogyakarta: Pustaka Pelajar.

Sajogyo, P., 1987. Pengembangan Peranan Wanita Khususnya di Pedesaan Yang Sedang Berubah dari Masyarakat Pertanian ke Industri di Indonesia 1981-1987. Seminar Fungsi Sosial Ekonomi Wanita Indonesia.

Singarimbun, M., dan Effendi, S. 1995. Metode Penelitian Survei. LP3ES, Jakarta.

Sudarmini, Ni Nyoman. 2006. Peranan Pekerja Perempuan dalam Menunjang Pendapatan Keluarga Pada Industri Kecil dan Kerajinan Rumah Tangga di Kabupaten Gianyar, Program Studi Magister IImu Ekonomi. Tesis tidak diterbitkan. Denpasar: PPS Universitas Udayana.

Sugioyono, 2001. Metode Penelitian Administrasi. Alfabeta. Bandung. 


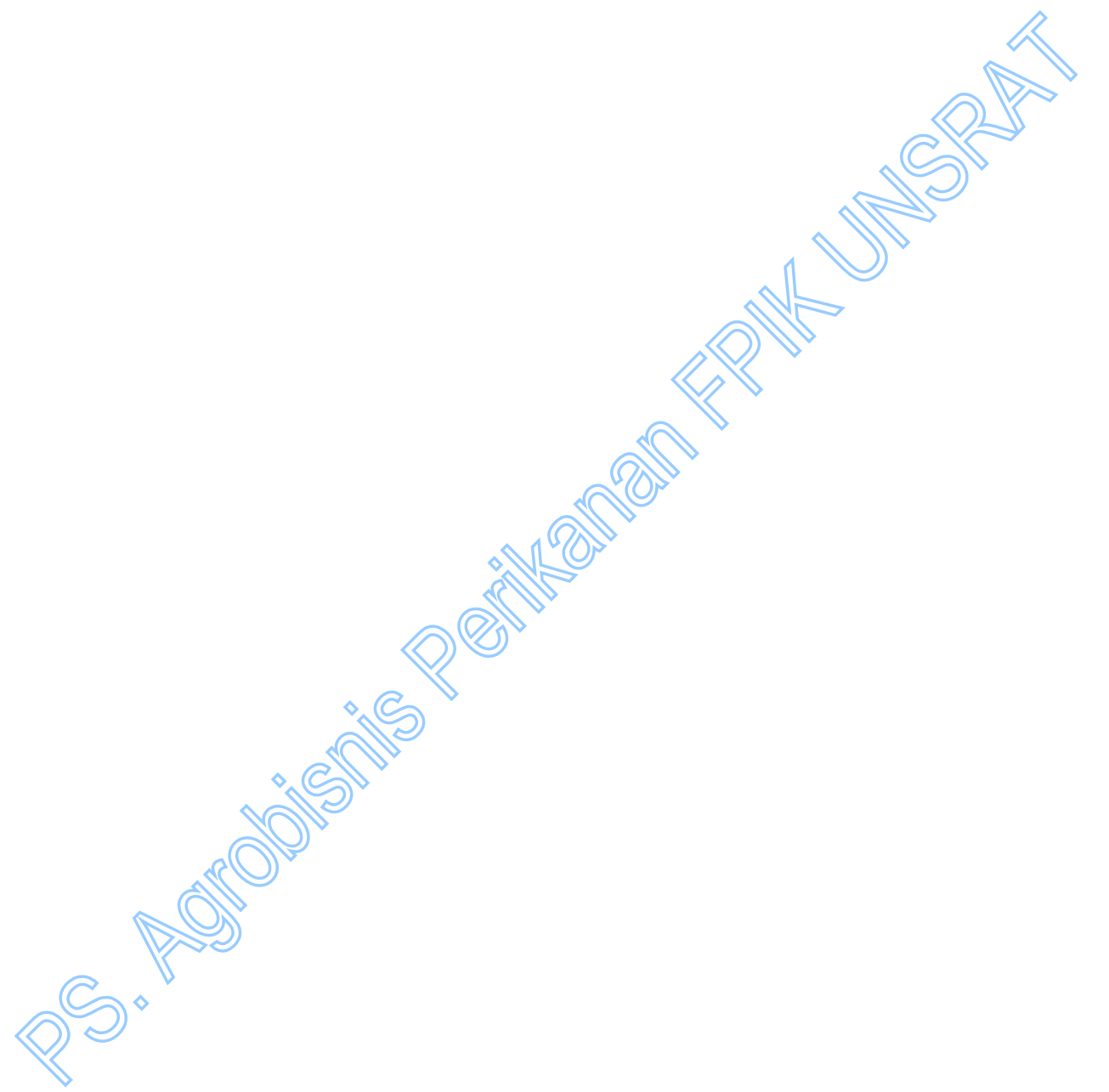

